\title{
Long-term studies of the habitat of Baikal organisms
}

LIMNOLOGY ERESHWATER

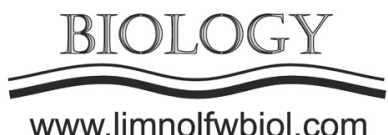

\author{
Khodzher T.V.*, Domysheva V.M., Tomberg I.V., Sakirko M.V., Sorokovikova L.M., \\ Golobokova L.P., Onischuk N.A., Obolkin V.A., Netsvetaeva O.G.
}

Limnological Institute, Siberian Branch of the Russian Academy of Sciences, Ulan-Batorskaya Str., 3, Irkutsk, 664033, Russia

\begin{abstract}
Lake Baikal is the world's largest unique freshwater body that more than 2600 species of various organisms inhabit, $70 \%$ of which are endemic. In recent decades, with climate change, a decrease in the humidity in the watershed area and the inflow of water to the lake, the discharge of insufficiently treated wastewater, the intensification of tourist activity, and an increase in the anthropogenic pressure on the atmosphere, the quality of water in the tributaries and littoral zone of Lake Baikal has significantly deteriorated, as evidenced from the results of numerous monitoring studies from 2008 to 2019.
\end{abstract}

Keywords: pelagic zone, littoral zone of Lake Baikal, tributaries, atmosphere, gases, aerosol, precipitation

A large data array (660 water samples from submarine stations in three basins of Lake Baikal) obtained from 2008 to 2018 confirms the stability of the ionic composition of water in the pelagic zone of Lake Baikal at all depths (Domysheva et al., 2019), which is similar to the results of previous studies (Votintsev, 1961). Based on the annual analysis of 300-350 samples in the pelagic zone of the lake, the dynamics of nutrients, nitrogen and phosphorus, is within the longterm fluctuations in spring (May-June), summer (July) and autumn (September-October) periods. Interannual changes in the upper $200 \mathrm{~m}$ water layer in the basins of the lake are due to the development of phytoplankton; changes in the water column deeper than $200 \mathrm{~m}$ are stable and do not exceed the errors of measurement methods. From 2014 to 2017, in the upper 100 m layer of the pelagic zone in Southern and Central Baikal, the silica concentration decreased significantly, which is probably associated with a decrease in its influx with the waters of the Selenga River resulted from a long period of low water level and mass development of algae (Fig.). A decrease in silica in the water column of the lake may be a cause of rearrangement in the structure of dominants of spring phytoplankton: the role of large-cell species of the genus Aulacoseira, which demand high silica concentrations in the environment, decreases, and the number of small-cell species of the genus Synedra increases (Bondarenko et al., 2019).

Since the late $20^{\text {th }}$ century, we have conducted the most complete hydrochemical studies of the main Baikal tributaries. Due to climatic fluctuations in the Baikal region, the inflow of river waters to the lake has significantly decreased in recent years, leading to a reduction in the outflow of Si from the Selenga River.
On the contrary, the outflow of $\mathrm{P}$ has increased over the past decade and averaged $1770 \mathrm{t} /$ year (Sorokovikova et al., 2019).

The study of river waters on the southeast coast of Lake Baikal (the Khara-Murin, the Pereyomnaya, the Solzan, the Utulik, and the Snezhnaya rivers) revealed a change in the relative composition of major ions and a decrease in the resistance to acidification in the modern period. The closure of the main source of anthropogenic emissions, the Baikalsk Pulp and Paper Mill, has reduced the anthropogenic pressure on the watersheds of the rivers in this area, but the process of water acidification, especially in the Pereyomnaya River is continuing, as evidenced by acid neutralizing capacity (ANC) that reflects the buffer capacity of the system to neutralize acids (from 1955 to 1960 - 219; from 2015 to 2018 121). Between 2015 and 2019, there were significant seasonal fluctuations and an increase in some elements in the watersheds on the southwest coast of Lake Baikal (the Krestovka, the Kamenushka, the Bolshaya Cheremchanka, and the Malaya Cheremshanka rivers) near Listvyanka, the Baikal's largest tourist settlement. The annual average concentrations of nitrates and ammonium in the watercourses were respectively 7-11 and 4-27 times higher than the data obtained upstream of the settlement, which is due to the influx of domestic sewage in the absence of a centralized sewage system as well as due to the atmospheric emissions.

An increase in the anthropogenic pressure on the coastal areas of Lake Baikal in the past decade has led to an increase in various forms of phosphorus and nitrogen in the water of the littoral zone, causing the mass development of the macroalgae species untypical of Lake Baikal and the disruption of the zonation in their 


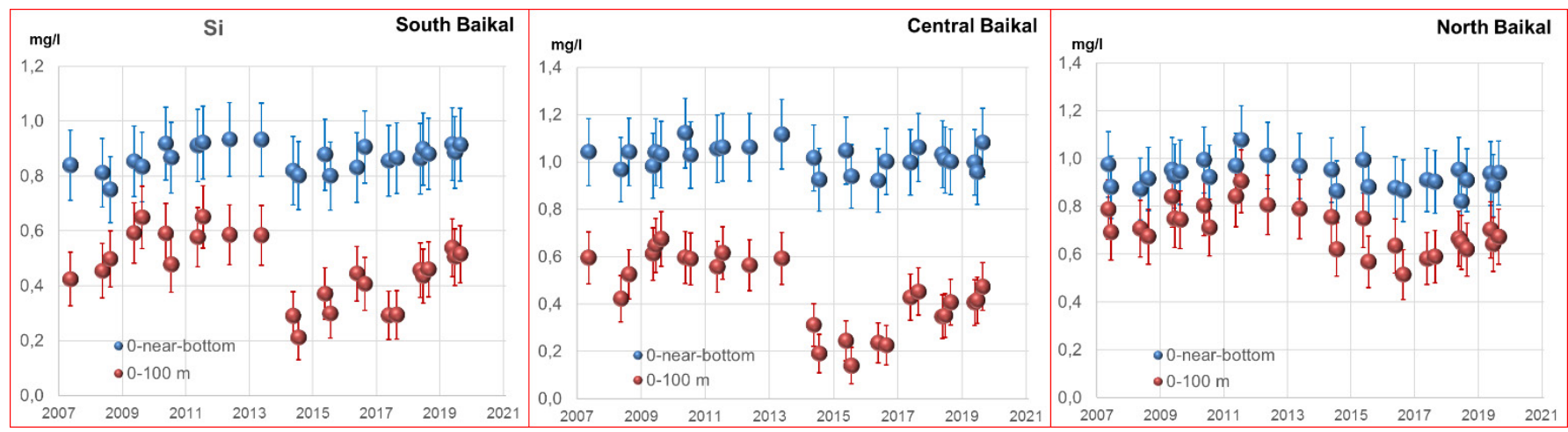

Fig. Interannual dynamics (from 2007 to 2019) of the weighted average concentrations of nitrate ions, silica and phosphate ions in different basins of Lake Baikal.

distribution natural for the ecosystem (Timoshkin et al., 2018). The concentrations of mineral phosphorus in the interstitial water reached $1000 \mu \mathrm{g} / 1$; the nitrogen concentration varied from 0.02 to $19 \mathrm{mg} / \mathrm{l}$. Nutrients coming from the coast support vegetation of benthic algae that are a source of organic matter themselves. The content of organic matter in the coastal waters of the Zarechny settlement (Northern Baikal) reached $77 \mathrm{mg} / \mathrm{l}$; the proportion of dissolved oxygen declined to $26 \%$ saturation, which characterizes this water as dirty. Based on the content of organic matter in some seasons, the coastal water in the Bolshoye Goloustnoye settlement is classified as dirty, and the coastal waters in the Bolshiye Koty settlement, the Severobaikalsk town (Senogda Bay) and the Listvyanka settlement are classified as polluted.

The data on long-term observations of gas impurities, aerosol and precipitation at the Listvyanka atmosphere monitoring station, as well as the data of ship measurements above the water area of the lake, indicate an increase in the concentrations of $\mathrm{SO}_{2}$ and $\mathrm{NO}_{2}$ in the atmosphere as well as the acid deposition with pH 4.4-4.6 in Southern Baikal. The ratio and growth of some ions in the aerosol composition change in the near-water atmosphere of Lake Baikal, which indicates possible changes in sources of their origin. During wildfires, the concentrations of potassium, sodium, sulfates, ammonium, heavy metals, and PAHs increase dramatically in the atmosphere above Lake Baikal. During a dry and wet deposition, they can enter the lake, polluting its water.

\section{Acknowledgements}

This study was carried out within the framework of the research project No. 0345-2019-0008 and the RFBR grants No. 18-45-030007 a, and RFBR-ofi No. 1729-05044.

\section{References}

Bondarenko N.A., Ozersky T., Obolkina L.A. et al. 2019. Recent changes in the spring microplankton of Lake Baikal, Russia. Limnologica 75: 19-29. DOI: 10.1016/j. limno.2019.01.002

Domysheva V.M., Sorokovikova L.M., Sinyukovich V.N. et al. 2019 Ionic composition of water in Lake Baikal, its tributaries, and the Angara River source during the modern period. Russian Meteorology and Hydrology 44: 687-694. DOI: $10.3103 /$ S1068373919100078

Sorokovikova L.M., Tomberg I.V., Sinyukovich V.N. et al. 2019. Low water level in the Selenga River and reduction of silica input to Lake Baikal. Inland Waters 9(4): 464-470. DOI: 10.1080/20442041.2019.1580078

Timoshkin O.A., Moore M.V., Kulikova N.N. et al. 2018. Groundwater contamination by sewage causes benthic algal outbreaks in the littoral zone of Lake Baikal (East Siberia). Journal of Great Lakes Research 44(2): 230-244. DOI: 10.1016/j.jglr.2018.01.008

Votintsev K.K. 1961. Gidrokhimiya ozera Baikal [Hydrochemistry of Lake Baikal]. Moscow: Publishing House of the USSR Academy of Sciences. (in Russian) 